Regional and Business Studies (2018) Vol 10 No 2, 1-10

Kaposvár University, Faculty of Economic Science, Kaposvár

doi: $10.33568 /$ rbs. 2332

\title{
THE EXPECTED EFFECT OF THE FOURTH INDUSTRIAL REVOLUTION ON THE HuNgarian TAX STRUCTURE
}

\author{
József VArga, Anita Ágoston, Balázs CsEH, Zoltán SiPICZKI \\ Kaposvár University, Faculty of Economic Science, H-7400 Kaposvár Guba S. u. 40.
}

\begin{abstract}
In our publication we examine the process of Industry 4.0, which has led to a significant transformation of production processes from the aspect of taxation. At the beginning of the paper, we offer a brief survey of the Fourth Industrial Revolution, analysing the operating mechanism of M2M (machine to machine) and IoT (Internet of things), which are based on large data and cloud-based data storage technology. After that we examine the expected future impact of these processes. The transformation process of the domestic tax system since 2010 bas been characterized by the decline in the proportion of taxes on labour and the increase in the proportion of turnover-type taxes. Our most important question is how the automation of the production processes influences the transformation of the tax system. This simulation study was carried out to compare different estimation procedures. Our new numerical results revels that the automation would result almost 6\% of GDP cost reduction on live labour force in 2015 on the basis of our calculation. This process is not reversible, so in the future it is necessary to reform the tax system and to increase the tax base corresponding to the reduction of the direct cost of live labour. Keywords: Industry 4.0, Fourth Industrial Revolution, Hungarian Tax Structure
\end{abstract}

\section{INTRODUCTION}

The publication examines some key elements of this process. The most important key issue is the taxation effect of replacing human labour with machine work. In the domestic public revenue system, the employer carries a considerable part of the human labour cost: in addition to the payment of the leave, the first 15 days of the sick pay and the 1/3 part of the rest of the sick pay. To this burden also comes the indirect carrying of the burden of disability pensions. This high tax incidence has a positive message from the point of view of our question. Our hypothesis is that automation improves the competitiveness of domestic employers, since the businesses will be set free from these cost elements, which are on the workforce.

Our second basic conception is that automation reduces unit costs for products. This, if it leads to the reduction of the sales price of the products, entails the reduction of the sales tax. Finally, in our study, we examine the process that the replacement with machine work creates open or hidden unemployment. In our work we analyse the future burdens of this replacement on the tax system, what new types of tax revenue opportunities can be made possible and necessary to offset the resulting unemployment. These new taxes will not be burdened with live labour, but will either give rise to a new consumption tax burden or some kind of taxation of the automation process. 


\section{THE OPERATING FRAMEWORK OF INDUSTRY 4.0}

Industry 4.0 means the fourth industrial revolution. This process causes also a complete transformation of our economy, the ever closer interconnection of information technology and automation, resulting in a radical transformation of production methods. With the machine-to-machine technology, M2M, the machines can also control continuously more complex processes, based on the ability to communicate with each other without human intervention. Hereby the productivity can significantly increase. The automation will embrace almost the entire spectrum of economic processes.

The presentation of the details of the technical processes of automation is not intended for this publication, but it is necessary to describe the concepts. Nowadays, not only the robotization, which was considered rightly important in education as well (Bánkuti and Paál, 1995), spreads and eliminates jobs. The real revolution has been brought about by the development and practical application of artificial sensing, regulation technique and artificial intelligence. The educational necessity of this was evident at our university, too. The machines, not only in the industry but also in households, have more and more artificial intelligence capabilities. They measure their status and make decisions. They can make their condition properties available remotely on the internet, or sharing with others (machines or people). Actually, several machines can make decisions that depend on each other's condition - without human intervention as well.

This Machine-Machine communication process requires an information channel. This is called the Internet of Things (IoT) because it is not a network, which is not used by people, but by machines. These processes create large data files. Their storage, due to their availability in the network, should be worked out with from everywhere accessible so-called cloud-based technology, which means databases, of course with strict access, but from any physical location secure accessible technology. These data and any other information, for example sales statistics (which are available immediately and in large quantities due to barcode systems), marketing or any other large amounts of data are investigated by Data Science Engineers. This is a new job created by this development and shows that a lot of workforce releases, but beside it develops fewer but more qualified jobs.

All this brings up what will happen to human labour that is released. The process and the question are not new; they have come up already several times in history, for example in the course of the Machine Revolution. The revolution of machine workforce during the first industrial revolution brought up movements, which would have liked to protect human labour and the interests of workers. These were the 18th and 19th century machine-breaking movements. The early - and even nowadays characteristic - machinebreaking movements can be divided into two groups: one is to protect the workers livelihood against wage cuts or rising prices, and the other one to protect the livelihood against the perceived or real threat of machines. These two are often confused and called "luddism", but neither of them are limited to protests against technical innovations. Rather, the aim was to put pressure on employers with a threat to ruin or dismantle their economic interests. Luddism was linked to the name of General Ned Ludd, or General Ludd, and the main feature was the technofobic machine destruction, but it is not the equal with it. It contains the various forms of struggle of employers, such as illegal organizing, negotiation with employers, riots, and sometimes armed clashes with the 
authorities and the destruction of entire factories. (Hobsbawn, 1952) Nowadays, neoluddism is against the development of modern technology and its widespread manifesttation, it presents a kind of technophobe tendency. Typically it is the passive abandonment of technology, the return to simple life, but it also involves action against technology-makers and sabotage efforts against technology supporters. Nevertheless, the NeoLuddian movements are also associated with other movements such as antiglobalization, anarcho-primitivism, anti-science and radical environmentalist movements.

At present, however, neo-luddism is based on concerns about technological impacts on individuals, communities, the human environment and its advocate the precautionary principle in respect of introducing, adopting, applying and encouraging new technologies. This is why it is against the industrial capitalism and the application of machine labour. The other paradigm is the transhumanist theory, which came into the front in our day and affects our theme. According to this, man either integrates with machines or becomes machine-friendly. Transhumanism technology seeks to eliminate illnesses, disabilities and ageing in relation to humans, so it has the most impact on taxes on labour taxation. As the most important risk, the extinction of the human race is highlighted, with complete automatism. (Kurzweil, 1999; Kaç2ynski, 1995) Justin Trudeau, Canada's 23rd Prime Minister, because of the spreading of the machine work, already integrates the Innovation and Skills item in the 2017 annual budget, which is based on the unemployment resulting in the development of the innovation economy (hence the development of a mechanical workforce). It allocates 132.4 million dollars for finance for 4 years, which should be spent on the maintenance of the employment of the insurance system. (Trudeau, 2017)

There is wide literature in economic literature as well. For example, Keynes speaks about "technological unemployment", if the potential of tools we have developed in order to save the labour force outweighs the potential of our job creation tools (Kerekes, 2017). Technological unemployment is mainly observed in transport logistics and office workplaces. Out of these areas, the field of the robot technology spreads in such fields, where it was hardly conceivable particularly, due the development of drones (the automation of a waiter's job).

Kevin Kelly, who also made a presentation in Hungary in 2017, said that 20 years later the development of artificial intelligence (AI) would reach the level that the automated workforce would be able to do jobs requiring more designed tasks, resulting in more job and work being superfluous, he analysed 12 types of work or other categories. (Kelly, 2016)

So we can say that two big "megatrends" are connected today. One is big data and mobilization (lots of data need to be efficiently analysed in such a way that it should be user-friendly and secure), or Industry 4.0. While in Web 3.0 physical production linked to IT, communication is nowadays not between people, but between machines as well. This includes Things of Internet, the Smart Factory. The background of this communication is the Internet and the intranet, the networking of systems and machines, the physical and cyber world where automation and IT are fully intertwined. Complexity is enhanced by the fact that financing and development services for production and innovation are also used on the Internet (Crowd Sourcing). The factories, and the complex of machines and software, hardware in them all regulate and optimize themselves, the value-creating process actually works 
on the base of cyberspace. This intelligent factory can change the production process without human intervention or opinion, so it can create efficiency and new collaborations (Szókea, 2015).

In connection with the fourth industrial revolution, it is important to examine the sustainability of the process. For the next period, a number of interconnected transformation processes are expected. "The new economy will have a low-carbon emission and cyclical economy, and the workforce will have a new role, due to the automated activities the employment capacity of production activities will be radically reduced. New employment areas will be needed to keep the "bored" citizens busy. (Kerekes, 2017)

From the centres, which work as the hotbed of innovation, the information flows out to peripheries in time, from where people and employees are "pushed" with non-violent devices to the centre.

\section{THEORETICAL TAXATION ASPECTS OF THE FOURTH INDUSTRIAL REVOLUTION}

In the wake of automatization, the rate of live labour lapses back in a hardly estimated degree. In countries where live labour is taxed in a high degree, tax loss will be significant with the reduction of the role of live labour as a result. In this way, when investigating the results connected to taxation, we should first of all review the structure of the tax system.

The conformation of the national tax system is adequately illustrated by chart 1 . Following the depression of the year 2008, the transformation of the tax system in Hungary came to fruition with the tendency of tax reduction afflicting labour. We can observe two different turnovers during the period of 2004-2015: the first one can be found in the period of 2004-2008 when the taxes afflicting labour showed a rising tendency, while the taxes that afflicted consumption showed a declining one. At this point, the trend shifted and it became more and more clear in the period of 2009-2015 that the rate of taxes that were connected to circulation and consumption rose to a degree of $45-46 \%$ from the rate of about $36 \%$ in 2008 , while the rate of taxes that afflicted labour dropped to the level of $45-46 \%$ from the rate of around $52 \%$ of the year 2008, which incorporated all revenue tariffs (V arga, 2017).

Regarding taxes that afflicted labour before 2010, the Hungarian tax system meant the highest rate of tax affliction and it was the most progressive tax system in the region. This type of tax system - with the relative large-scale social support system of inactive lawyers of the society - resulted in Hungary's place among the countries that had the lowest activity rate in the European Union. Therefore, the tax system of Hungary is characterized by the moderation of taxes afflicting labour. In this perspective, the Hungarian tax system is less exposed to automatization.

In recent years, significant changes connected to the tax structure took place on the level of the European Union, too. Regarding the taxes that afflict labour, there is no recognizable integrated tendency. Concerning our most important case, Germany, the level of taxes that afflict labour is high, however, it shows a declining tendency (Takács et al, 2014). The tax revenues of the German national budget are constituted by the incomes that stem from the personal income tax besides the incomes of the value-added tax. Being aware of this fact the question arises how the degree of the income of the German national budget can be sustained with the mass spread of future automatization. 
Figure 1

\section{The proportion of individual tax rates as a percentage of total tax revenue in Hungary}

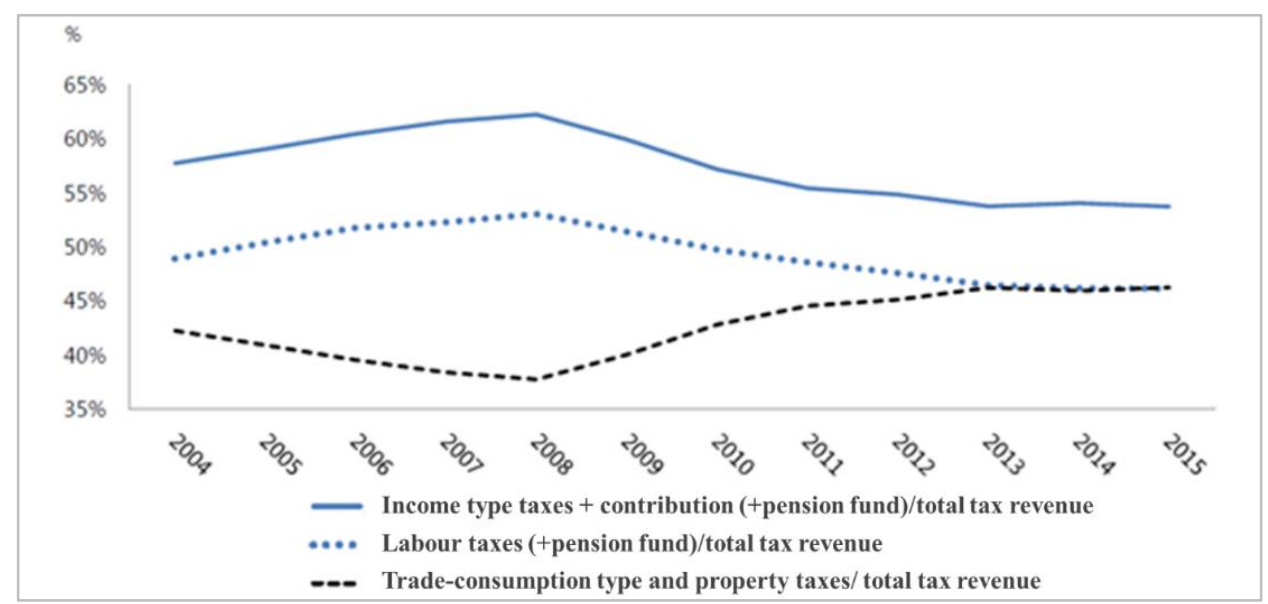

Source: Izer, 2016

In Hungary, tax changes that affected the burdens of live labour accelerated in 2010, when the personal income tax was changed for the flat personal income tax rate (from its former 18 and $36 \%$ level) of 16\%. In order to counterbalance this, circulation was taxed to a higher and higher degree, which was realized in a $27 \%$ rate of VAT and a raised level of excise tax, not to mention the so-called supertaxes (financial institutions, energy sector). The government's politics, which was devoted to relief from taxation, proceeded in 2016, when labour afflicting taxes continued to dwindle. The degree of personal income tax was moderated from $16 \%$ to $15 \%$. According to Domonkos, the procedure persists during which the major objectives must be the "whitening" of the economy and the increase of the effectiveness of tax collection since the gradation of the effectiveness of tax collection is not a self-interest but a means to reduce tax rates, hereby to improve the competitiveness of the economy (Domokos, 2016). A quintessential change occurred in 2017 regarding the effort to moderate the burdens of live labour. The rate of social contribution dropped from $27 \%$ to $22 \%$. A further step of mitigation is predicted for 2018 , to a rate of $20 \%$.

On a macro-level, we can assert that as essential elements, the Hungarian tax changes of the years of 2016-2017 contribute significantly to the reduction of tax burdens in accordance with the rate of GDP, respectively to the abatement of the rate of taxes afflicting labour. It is a possible future vision that the degree of taxes afflicting labour will be reduced under the level of circulation-property taxes.

\section{RESULTS AND DISCUSSION}

In the last part of our publication, we estimate the reduction of the workload-burden that can be saved because of automation. The starting data are actual data, however 
the degree of automation and its economic impact can only be considered with very uncertain forecasts.

Table 1

The direct burden of live workforce in Hungary (2015)

\begin{tabular}{|c|l|c|}
\hline $\begin{array}{c}\text { Ordinal } \\
\text { number }\end{array}$ & \multicolumn{1}{|c|}{ Designation } & Amount (billion HUF) \\
\hline 1. & Social security income & 4489 \\
\hline 2. & Personal income tax & 1689 \\
\hline 3. & Taxes on total wages and on number of workforce & 200 \\
\hline & Sum total & 6378 \\
\hline
\end{tabular}

Source: Based on CSO data

According to the data of the CSO (Hungarian Central Statistical Office), the amount of social security revenue in Hungary was 4489 billion HUF in 2015 (Table 1). This amount can be used as a basis for workforce-burden. The personal income tax must be added to this amounting to 1689 billion HUF (CSO: 3.7.2 The revenues of the central budget (2005-)), and the taxes on total wages and on the number of workforce, which is 200 billion HUF (as shown in Table 2) ${ }^{1}$. This is total 6378 billion HUF, which can be taken into consideration as a direct burden of labour. This was about $20 \%(18.5 \%)$ of GDP (34 324 billion $\mathrm{HUF}^{2}$ ) in 2015.

For this amount we can add, as an indirect burden on living labour, the amount of leave (the machines do not go on holiday), the amount of sick pay (the machines do not get sick, if they are broken down, their repair can be done generally quickly) and family support amounts. In details:

- the amount of leave,

- the amount of the first 15 days of sick pay

- the $1 / 3$ of the amount of sick pay after the first 15 days

- the amount of disability pensions.3

The amount of workload reduction caused by automation is required to determine the size of the above workload-burden, so the amount of live work savings can be calculated from the product of multiplication of the two data. This second data "of course" moves within very wide limits, so this future impact is very difficult to estimate. Figure 2 and Table 3 give an estimate of the expected effects of automation (Kerekes, 2017). For further calculations, we use the middle data of the middle value.

\footnotetext{
13.1.16.1. Revenue from taxes and social security contributions - Government + Institutions of the European Union (1995-), D29C line.

23.1.2. The value of gross domestic product (GDP) in HUF, EUR, USD, purchasing power parity (1995-)

${ }^{3}$ The quantification of indirect costs is planned in a later publication.
} 
Table 2

\section{Revenue from taxes and social security contributions - Government + Institutions of the European Union at current prices, HUF billion}

\begin{tabular}{|c|c|c|c|c|c|c|c|c|c|}
\hline Code & Row similarity & 2008 & 2009 & 2010 & 2011 & 2012 & 2013 & 2014 & 2015 \\
\hline D.61 Net social contributions & $\begin{array}{c}59=60-63+66+ \\
69+77\end{array}$ & 3668 & 3412 & 3247 & 3686 & 3734 & 3907 & 4204 & 4489 \\
\hline $\begin{array}{l}\text { D.611 Actual social contributions } \\
\text { of employers }\end{array}$ & $\begin{array}{c}60=61+62 \\
=64+65\end{array}$ & 2595 & 2375 & 2084 & 2200 & 2161 & 2236 & 2444 & 2597 \\
\hline $\begin{array}{l}\text { D.611C Actual compulsory social } \\
\text { security contributions for } \\
\text { employers }\end{array}$ & 61 & 2595 & 2375 & 2084 & 2200 & 2161 & 2236 & 2444 & 2597 \\
\hline $\begin{array}{l}\text { D.611V Actual voluntary social } \\
\text { contributions of employers }\end{array}$ & 62 & - & - & - & - & - & - & - & - \\
\hline $\begin{array}{l}\text { D.61SC Service charges for social } \\
\text { security systems }\end{array}$ & 63 & .. & .. & .. & .. & .. & .. & .. & .. \\
\hline $\begin{array}{l}\text { D.6111 Employer's actual } \\
\text { pension contributions }\end{array}$ & 64 & .. & .. & .. & .. & .. & .. & .. & .. \\
\hline $\begin{array}{l}\text { D.6112 Actual non-pension } \\
\text { contributions for employers }\end{array}$ & 65 & .. & .. & .. & .. & .. & .. & .. & .. \\
\hline $\begin{array}{l}\text { D.612 Employer imputed social } \\
\text { contributions }\end{array}$ & $66=67+68$ & 23 & 24 & 25 & 23 & 21 & 22 & 24 & 28 \\
\hline $\begin{array}{l}\text { D.6121 Employer imputed } \\
\text { pension contributions }\end{array}$ & 67 & - & - & - & - & - & - & - & - \\
\hline $\begin{array}{l}\text { D.6122 Employer imputed non- } \\
\text { pension contributions }\end{array}$ & 68 & 23 & 24 & 25 & 23 & 21 & 22 & 24 & 28 \\
\hline $\begin{array}{l}\text { D.613 Actual social contributions } \\
\text { of households }\end{array}$ & $\begin{array}{c}69=70+71 \\
=72+76\end{array}$ & 1050 & 1013 & 1138 & 1463 & 1552 & 1650 & 1735 & 1865 \\
\hline $\begin{array}{l}\text { D.6131 Actual pension } \\
\text { contributions of households }\end{array}$ & 70 & .. & .. & .. & .. & .. & .. & .. & .. \\
\hline $\begin{array}{l}\text { D.6132 Actual non-pension } \\
\text { contributions of households }\end{array}$ & 71 & .. & .. & .. & .. & .. & .. & .. & .. \\
\hline $\begin{array}{l}\text { D.613C Actual statutory social } \\
\text { contributions of households }\end{array}$ & $72=73+74+75$ & 1048 & 1011 & 1137 & 1461 & 1551 & 1649 & 1734 & 1864 \\
\hline $\begin{array}{l}\text { D.613CE Actual compulsory } \\
\text { social security contributions for } \\
\text { employees }\end{array}$ & 73 & 862 & 823 & 971 & 1290 & 1428 & 1553 & 1661 & 1784 \\
\hline $\begin{array}{l}\text { D.613CS Actual compulsory } \\
\text { social security contributions for } \\
\text { self-employed persons }\end{array}$ & 74 & 102 & 105 & 84 & 90 & 90 & 55 & 51 & 56 \\
\hline $\begin{array}{l}\text { D.613CN Actual compulsory } \\
\text { social security contributions for } \\
\text { non-employees }\end{array}$ & 75 & 84 & 83 & 82 & 81 & 33 & 40 & 23 & 23 \\
\hline $\begin{array}{l}\text { D.613V Actual voluntary social } \\
\text { contributions of households }\end{array}$ & 76 & 2 & 2 & 2 & 2 & 2 & 2 & 1 & 1 \\
\hline $\begin{array}{l}\text { D.614 Complementary social } \\
\text { contributions of households }\end{array}$ & $77=78+79$ & - & - & - & - & - & - & - & - \\
\hline $\begin{array}{l}\text { D.6141 Additional pension } \\
\text { contributions of households }\end{array}$ & 78 & - & - & - & - & - & - & - & - \\
\hline $\begin{array}{l}\text { D.6142 Additional non-pension } \\
\text { contributions of households }\end{array}$ & 79 & - & - & - & - & - & - & - & - \\
\hline
\end{tabular}

Source: CSO 3.1.16.1. table 
Table 3

Probability of Computerisation

\begin{tabular}{|l|c|c|c|}
\hline \multirow{2}{*}{\multicolumn{1}{|c|}{ Variable }} & \multicolumn{3}{c|}{ Probability of Computerisation } \\
\cline { 2 - 4 } & Low & Medium & High \\
\hline Assisting and caring for others & $48 \pm 20$ & $41 \pm 17$ & $34 \pm 10$ \\
\hline Persuasion & $48 \pm 7,1$ & $35 \pm 9,8$ & $32 \pm 7,8$ \\
\hline Negotiation & $44 \pm 7,6$ & $33 \pm 9,3$ & $30 \pm 8,9$ \\
\hline Social perceptiveness & $51 \pm 7,9$ & $41 \pm 7,4$ & $37 \pm 5,5$ \\
\hline Fine arts & $12 \pm 20$ & $3,5 \pm 12$ & $1,3 \pm 5,5$ \\
\hline Originality & $51 \pm 6,5$ & $35 \pm 12$ & $32 \pm 5,6$ \\
\hline Manual dexterity & $22 \pm 18$ & $34 \pm 15$ & $36 \pm 14$ \\
\hline Finger dexterity & $36 \pm 10$ & $39 \pm 10$ & $40 \pm 10$ \\
\hline Cramped work space & $19 \pm 15$ & $37 \pm 26$ & $31 \pm 20$ \\
\hline
\end{tabular}

Source: Kerekes (2017)

Estimation of the likelihood of automation is given in Table 3. For the accurate calculation, the total economic weight of each sector would be needed to be multiplied with the probability data. As this data are not available for Hungary broken down according to the table, in our present publication we assume a medium degree of total workflow automation. Based on the averages of the middle column of the table the mean value is $33 \%$ (with unweighted calculation). Therefore, automation touches approximately the $1 / 3$ part of the production value.

\section{Figure 2}

The actual amount of the real and the expected reduced costs due to automation based on the direct cost of labour force in Hungary (2015)

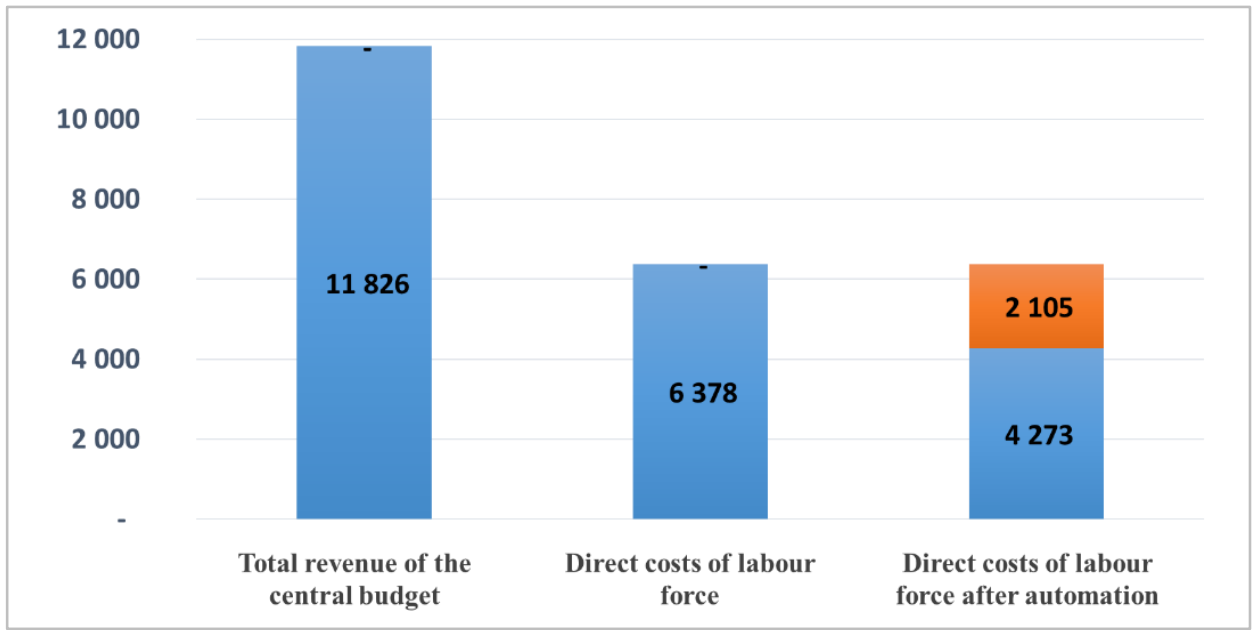

Source: Based on CSO 
In conclusion, we can establish that in Hungary in respect to 2015, based on the direct costs of labour force with the 6378 billion HUF, almost 1/3, or 2105 billion HUF derive from saving because of automation. The automation would have resulted in almost $6 \%$ of GDP cost reduction on live labour force in 2015 on the basis of our calculation. This process is not reversible, so in the future it is necessary to reform the tax system and to increase the tax base corresponding to the reduction of the direct cost of live labour.

\section{ACKNOWLEDGEMENT}

Supported through the New National Excellence Program of the Ministry of Human Capacities

\section{REFERENCES}

Bánkuti, Gy., Paál, J. (1995): A robottechnika multimédia az oktatásban. A robottechnika oktatása. In: Multimédia alkalmazása az oktatásban workshop. Keszthely: PATE GEORGIKON Kar, 23-24. March 1995, 52-53. p. [online] <URL: http://www.digkep.hu/konferencia/konf/MMO95/kiadvany.pdf>

Domokos, L. (2016): Versenyképesség, állami szerep, állammenedzsment. Kecskemét: 54. Közgazdász-vándorgyúlés, 2016. szeptember 17. [online] <URL: http://www.mkt.hu/wp-content/uploads/2016/09/Domokos_Laszlo.pdf>

György, L., Veress, J. (2016): 2010 utáni magyar gazdaságpolitikai modell. In: Pénzügyi Szemle, 2016. 3. 367-388. p.

Hobsbawn, E.J. (1952): The Machine Breakers, In: Past and Present, 1. 1. 57-70. p. doi: $10.1093 /$ past/1.1.57

Izer, N. (2016): A kormányzati adópolitika és az adóhatóság feladatrendszere. In: Kihívások és nemzettudat a modern pénzügyekben. X. Soproni Pénzügyi Napok. Sopron, 29-30 Sept. 2016. [online] <URL: http://spek.hu/index.php?page= konferencia_2016_X_soproni_penzugyi_napok_letoltesek>

Kaczynski, T. (1995): The Unabomber Manifesto, Industrial Society and Its Future In: New York Times 1995 June [online] <URL: http://editions-hache.com/ essais/pdf/kaczynski2.pdf>

Kelly, K. (2016): The Inevitable: Understanding the 12 Technological Forces That Will Shape Our Future. New York City: Viking press, 336 p.

Kerekes, S. (2017): A jövő elkezdődött? A 4. ipari forradalom és a fenntarthatóság. Kaposvár: Régiók a Kárpát-medencén innen és túl konferencia. 2017.

Kurzweil, R. (1999): The Age of Spiritual Machines. New York City: Viking Adult, 400. p.

Mosberger, P. (2017): Egykulcsos társasági adó hatása. [online] <URL: http://mnb.hu/letoltes/mosberger-palma-egykulcsos-tarsasagi-ado-hatasa.pdf $>$

Szóka, K. (2015): Controlling kihívások és trendek 2015-ben. In: Székely Cs., Kulcsár L. (Eds.): Strukturális kihívások - reálgazdasági ciklusok: Innovatív lehetőségek a valós és virtuális világokban: Nemzetközi tudományos konferencia a Magyar 
Tudomány Ünnepe alkalmából: Tanulmánykötet. Sopron: Nyugatmagyarországi Egyetem Kiadó, 149-158. p.

Takács, V., Máté, Á., Nagy, S. Gy. (2014): Adószerkezeti változások az Európai Unióban. In: Köz-gazdaság, 9. 4. 127-144. p.

Varga, J. (2017): Az adóteher-csökkentés és a gazdaság kifehérítésének pályája Magyarországon 2010 után In: Pénzügyi Szemle 62. 1. 7-20. p.

Trudeau, J. (2017): What should governments do to prepare for the technological automation of human jobs? [online] <URL: https://www.quora.com/Whatshould-governments-do-to-prepare-for-the-technological-automation-ofhuman-jobs>

Corresponding author:

\section{József VARGA}

Kaposvár University

Faculty of Economic Science

H-7400 Kaposvár, Guba Sándor u. 40.

e-mail: varga.jozsef@ke.hu 